\title{
PERIKANAN BUDIDAYA DI DANAU MANINJAU: Antisipasi Kebijakan Penanganan Dampak Kematian Masal Ikan
}

\author{
Zahri Nasution, Yesi Dewita Sari dan Hakim Miftakhul Huda \\ Balai Besar Penelitian Sosial Ekonomi Kelautan dan Perikanan, \\ Jalan K.S Tubun Petamburan VI, Jakarta 10260
}

Diterima 26 Oktober 2011 - Disetujui 11 Desember 2011

\begin{abstract}
ABSTRAK
Kematian ikan secara massal sebanyak 950 ton di Danau Maninjau, Sumatera Barat yang pertama kali terjadi pada tahun 1997, mengakibatkan kerugian sebesar Rp. 2,7 milyar. Kematian massal selanjutnya terjadi pada awal Januari 2009 dan terulang kembali pada akhir Februari serta awal Maret 2010 dengan tingkat kematian ikan mencapai 1.150 ton. Kajian ini bertujuan untuk menganalisa opsi kebijakan antisipasi dalam penanganan dampak kematian massal ikan di Danau Maninjau. Kajian ini dilakukan menggunakan pendekatan analisis kebijakan dengan hasil bahwa dampak ekonomi kematian massal ikan budidaya yang terjadi pada dua (2) nagari di Danau Maninjau pada periode 23 Februari - 13 Maret 2010 mengakibatkan kerugian finansial sebesar Rp 13,93 milyar bagi para pembudidaya ikan. Kerugian tersebut terdiri atas dampak kerugian ekonomi kematian ikan, potensi keuntungan yang hilang bagi pembudidaya ikan, pedagang pakan ikan dan pedagang ikan. Dampak sosial yang diperhitungkan secara ekonomi adalah hilangnya sumber mata pencaharian, sejumlah tenaga kerja dalam tata niaga budidaya ikan sistem karamba jaring apung (KJA) bersumber dari adanya peningkatan hutang untuk melanjutkan usaha. Kajian ini menghasilkan lima opsi antisipasi kebijakan dalam penanganan dampak kematian massal ikan di Danau Maninjau.
\end{abstract}

Kata Kunci: kerugian ekonomi, dampak sosial, kematian masal ikan, keramba jaring apung, danau Maninjau

Abstract: Aquaculture in Lake Maninjau: Policy Anticipation to Handle Impacts of Fish Kills. By: Zahri Nasution, Yesi Dewita Sari and Hakim Miftakhul Huda

Massive fish kills with about 950 tons in Lake Maninjau of West Sumatra was firstly occurred in 1997 impacted a financial loss of IDR 2.7 billion. Further fish kills were occurred in early January 2009 and were followed in late February and early March 2010 with number of 1,150 tons fish kills. This research aims to analyze options for policy anticipation to handle impacts of fish kills in Lake Maninjau. This research used a policy analysis approach and the results showed that the economic impacts of fish kills in two villages during 23 February to 13 March 2010 accounted for IDR 13.93 billion. Economic loss consists of the fish kills impacts including potential profit loss from fish farmers, traders, fish feed and fish traders. Calculated social impacts in economic terms were a loss number of livelihood and source of incomes from floating net cage aquaculture by which lead to debt increasing. This research produced five options for policy anticipation to handle impacts of fish kills.

Keywords: economic losses, social impacts, mass fish kills, floating net cages, Lake Maninjau 


\section{PENDAHULUAN}

Kematian ikan secara masal di Danau Maninjau, Sumatera Barat pertama kali terjadi pada tahun 1997, menyebabkan kematian ikan sebanyak 950 ton dan mengakibatkan kerugian sebesar Rp. 2,7 milyar (Syandri, 2004). Pada saat itu, jumlah KJA baru mencapai 2.854 unit. Kematian ikan secara masal kembali terjadi pada awal Januari tahun 2009 dengan kerugian mencapai Rp 150 milyar dari 13.413 ton ikan yang mati. Terakhir, fenomena kematian ikan secara masal kembali terjadi pada tahun 2010, tepatnya mulai tanggal 23 Februari dan puncak kematian ikan pada tanggal 13 Maret 2010. Pada kurun waktu tersebut ikan mati mencapai 1.150 ton yang melanda wilayah Nagari Maninjau dan Bayur.

Berdasarkan data yang dimiliki Badan Pengendalian Dampak Lingkungan Hidup Daerah Sumatera Barat, saat terjadinya kematian ikan secara masal pada awal Januari 2009, perairan Danau Maninjau mengandung amonia 0,2-1,07 $\mathrm{mg} / \mathrm{L}$ atau lebih besar dari ambang batas yang diperbolehkan untuk kegiatan perikanan yaitu $0,02 \mathrm{mg} / \mathrm{L}$. Kandungan Nitrit mencapai 0,07-0,21 mg/L atau jauh diatas batas toleransi untuk kegiatan perikanan $0,06 \mathrm{mg} / \mathrm{L}$. Tingginya kandungan amonia dan nitrit tersebut mengakibatkan kematian ikan secara masal ketika terjadi umbalan atau naiknya kedua senyawa tersebut ke permukaan perairan danau (Sawyer, 1969). Selain itu, posisi sebagian KJA yang berada pada kedalaman $<10$ meter menyebabkan ikan dalam KJA cepat terkontaminasi racun dari sedimen danau.

Kejadian pada awal Januari 2009 terulang kembali pada akhir Februari dan awal Maret 2010. Danau Maninjau, Propinsi Sumatera Barat beberapa pekan pada bulan Maret 2010 (saat terjadinya kematian ikan secara masal) mengandung amoniak yang relatif tinggi $(0,5 \mathrm{ppm})$ sedangkan kandungan oksigen terlarutnya relatif rendah hingga 4,75 ppm. Berbagai sumber (KKP dan Dinas Kelautan dan Perikanan Propinsi Sumatera Barat) menyebutkan bahwa kematian ikan adalah karena terjadi umbalan/upwelling dan olakan air danau. Dengan demikian, kejadian kematian massal ikan budidaya pada sistem KJA di perairan Danau Maninjau, bukan saja sebagai akibat dampak adanya kegiatan budidaya ikan sistem KJA yang belum tertata dengan baik sesuai dengan tata ruang yang telah diatur untuk tujuan keberlanjutan pemanfaatan sumberdaya perairan danau ini. Kematian massal tersebut juga dipacu dengan adanya perubahan iklim yang akhir-akhir ini banyak terjadi angin kencang diatas perairan baik yang datang dari arah utara maupun selatan wilayah danau. Angin yang kencang tersebut mengakibatkan terjadinya gelombang yang dibarengi dengan potensi kelebihan pakan ikan yang diberikan pada kegiatan budidaya menimbulkan fenomena "up-welling" pada perairan tersebut.

Kematian masal ikan budidaya pada sistem KJA ini mengakibatkan timbulnya kerugian ekonomi dan juga berdampak sosial baik secara langsung maupun tidak langsung terhadap masyarakat pembudidaya ikan dan masyarakat lainnya yang berkaitan dengan usaha budidaya ikan sistem KJA tersebut. Analisis kebijakan ini bertujuan mengemukakan dampak ekonomi dan sosial kematian ikan budidaya pada sistem KJA pada perairan Danau Maninjau yang terjadi pada periode Januari - Maret 2010. Disamping itu, kegiatan ini bertujuan mengidentifikasi permasalahan dan berupaya merumuskan opsi kebijakan yang diperlukan agar pemanfaatan perairan Danau Maninjau dapat berlangsung secara berkelanjutan sesuai dengan prinsip-prinsip pembangunan perikanan berkelanjutan sebagaimana yang dimaksudkan (Hare et al., 1990).

\section{METODOLOGI}

\section{Kerangka Pikir}

Kegiatan usaha perikanan di wilayah perairan Danau Maninjau didominasi oleh kegiatan perikanan budidaya dengan komoditas utama adalah ikan Nila dan Mas. Kegiatan budidaya ikan yang dilakukan sejak tahun 1992 ini di kawasan Danau Maninjau adalah mulai 
dari pembenihan, pendederan sampai dengan pembesaran untuk ikan Nila sedangkan untuk ikan Mas adalah pendederan dan pembesaran (LIPI, 2009). Aktifitas ini menambah manfaat ekonomi Danau Maninjau yang dibangun pada tahun 1985 sebagai pembangkit listrik tenaga air (PLTA).

Pada mulanya jumlah keramba jaring apung yang diusahakan sebanyak 12 unit dimana tiap unit KJA terdiri dari 4 petak. Empat tahun kemudian (1996) terjadi peningkatan jumlah keramba hingga 157 kali lipat atau sebanyak 1.886 unit. Pada tahun 1997 terjadi kematian masal ikan akibat penurunan kualitas air, sehingga jumlah KJA mengalami penurunan (LIPI, 2009). Pada tahun 2007 sampai dengan 2009 jumlah KJA mengalami peningkatan dari 10.148 unit pada 2007 menjadi 12.106 unit pada 2008 dan menjadi 15.051 unit KJA pada 2009 di hampir seluruh kawasan perairan danau.

Pada umumnya keramba yang diusahakan menggunakan model rakit dari kayu (bambu) dengan ukuran $5 \times 5 \times 4$ meter. Ikan-ikan dalam KJA ini diberi makan dengan pakan buatan (pellet). Produksi ikan Nila dan Mas pada KJA antara tahun 2005 sampai dengan 2008 terus mengalami peningkatan, sedangkan pada tahun 2009 mengalami penurunan sebagai akibat terjadinya kematian ikan secara masal pada awal tahun 2009. Peningkatan jumlah KJA di perairan danau telah meningkatkan limbah KJA, yang pada akhirnya memberikan dampak negatif terhadap lingkungan perairan. Terjadinya eutrofikasi yang lebih cepat dengan frekuensi yang sering, sehingga menyebabkan mutu perairan menjadi menurun. Hal ini merupakan salah satu contoh dampak dari peningkatan jumlah limbah KJA (Krismono dan Krismono, 1998). Demikian juga halnya dengan limbah sisa pakan dan kotoran ikan yang menumpuk di dasar perairan danau, untuk selanjutnya mengalami dekomposisi atau penguraian.

Peningkatan buangan bahan organik ke dasar perairan danau akan merangsang aktivitas bakteri, jamur dan makro-invertebrata, sehingga meningkatkan konsumsi oksigen di sedimen. Akibat jumlah sisa pakan cukup banyak, menyebabkan terjadinya kondisi anaerob di daerah perairan (Kartamihardja, 1995). Oleh karena itu, menurut Krismono (1996), kejadian kematian ikan masal dapat saja disebabkan adanya pengadukan (pembalikan) massa air yang disebut dengan turn-over (umbalan) pada saat penggantian musim kemarau ke musim hujan atau pada saat terjadinya angin kencang.

Tingginya konsentrasi fosfat, selain dari sisa pakan diduga juga berasal dari limbah manusia dan limbah domestik lainnya yaitu berupa tinja dan deterjen. Setiap tahunnya beban limbah fosfor $(P)$ dari deterjen yang masuk ke perairan danau. Hal ini akan menstimulir peningkatan kandungan fosfat dan kekeruhan di perairan danau. Kelebihan kesuburan perairan inilah yang mengakibatkan terjadinya kematian ikan secara masal, yang menimbulkan kerugian secara sosial maupun ekonomi.

\section{Pendekatan dan Metoda Analisis}

Studi ini dilakukan menggunakan pendekatan analisis kebijakan, yaitu suatu bentuk analisis yang menghasilkan dan menyajikan informasi sedemikian rupa sehingga dapat memberi landasan dari para pembuat kebijakan dalam membuat keputusan (Dunn, 2000). Dalam hal ini, termasuk di dalamnya kegiatan evaluasi dan mensintesis informasi, termasuk hasil-hasil penelitian, untuk akhirnya menghasilkan rekomendasi opsi desain kebijakan publik (Simatupang, 2003).

Data yang dkumpulkan dalam penelitian ini terdiri dari dua jenis, yaitu data primer dan data sekunder. Data sekunder merupakan informasi umum tentang perkembangan isu aktual yang diteliti serta kendala yang dihadapi pada berbagai pemangku kepentingan (stakeholder). Data primer yang dikumpulkan yang terkait dengan dampak ekonomi meliputi biaya yang terkait produksi, yang terdiri dari biaya operasional dan biaya tetap. Kemudian data yang terkait dengan potensi keuntungan yang hilang pada pedagang pakan ikan dan 
pedagang ikan. Juga data yang terkait dengan dampak sosial meliputi hilangnya mata pencaharian tenaga kerja dan pendapatan nagari serta jumlah hutang pembudidaya. Data sekunder dikumpulkan melalui penelusuran pustaka dan dengan memanfaatkan data yang dikeluarkan oleh unit kerja, serta dari berbagai nara sumber dan hasil penelitian lembaga lainnya dengan topik yang serupa.

Responden kunci adalah informan yang digunakan sebagai sumber informasi dan data yang diperlukan dalam kegiatan ini. Informan tersebut adalah Penyuluh Perikanan, staf Balai Pelaksana Penyuluh Pertanian, Perikanan, Kehutanan dan Ketahanan Pangan (BP4K2P) Kecamatan Tanjung Raya. Kemudian, informan lainnya adalah staf Dinas Kelautan dan Perikanan Kabupaten Agam (di Lubuk Basung), tokoh adat setempat dan masyarakat pembudidaya ikan yang berada di Nagari Maninjau dan Bayur. Data yang dikumpulkan ditabulasi dan dideskripsikan untuk selanjutnya dianalisis secara deskriptif serta diinterpretasikan secara logis (Nazir, 1988).

\section{DAMPAK EKONOMI KEMATIAN IKAN SECARA MASAL}

Kejadian kematian ikan pada awal tahun 2010 terjadi pada periode 23 Februari sampai dengan 13 Maret. Kejadian yang terjadi pada periode 23 februari sampai dengan 12 Maret hampir terjadi di seluruh nagari di yang melingkupi perairan Danau Maninjau. Kematian ikan pada periode ini hanya 2-3 kg setiap paginya pada masingmasing karamba. Kejadian kematian ikan pada tanggal 13 Maret menyebabkan kematian ikan hampir 70\% karamba yang terdapat di dua nagari yaitu Nagari Maninjau dan Nagari Bayua. Total kematian ikan pada hari tersebut diperhitungkan sebanyak 500 ton. Jumlah karamba yang terdapat di kedua nagari tersebut adalah 1.737 unit.

Kerugian ekonomi akibat kematian ikan secara masal yang terjadi pada 23 Februari 2010 sampai dengan 13 Maret 2010 mencakup beberapa dimensi; yaitu: (a) besarnya kerugian biaya produksi yang dialami oleh pembudidaya karena ikan yang telah dipelihara selama lebih dari 2 bulan mengalami kematian secara masal; (b) potensi keuntungan pembudidaya yang hilang karena ikan tersebut tidak dapat dijual; (c) potensi keuntungan pedagang pakan ikan yang hilang karena berkurangnya penggunaan pakan; dan (d) potensi keuntungan pedagang ikan yang hilang karena ikan-ikan tersebut tidak jadi dipanen dan tidak dapat dijual.

Kerugian pembudidaya karena telah mengeluarkan biaya untuk membesarkan ikan-ikan yang mengalami kematian dilihat dari biaya operasonal dan biaya tetap untuk pemeliharaan selama 3 bulan. Biaya operasional yang diperhitungkan terdiri dari biaya untuk pembelian benih dan pakan, upah tenaga kerja dan pembayaran listrik. Biaya tetap terdiri dari biaya penyusutan karamba, bambu, perahu dan rumah untuk penyimpanan pakan. Satuan biaya yang dihitung adalah untuk 1 petak karamba dengan jaring berukuran panjang dan lebar $5 \mathrm{~m}$ serta kedalaman $4 \mathrm{~m}$.

Jenis ikan yang dibudidayakan terdiri dari ikan mas dan ikan nila. Jumlah karamba yang digunakan untuk membudidaykan ikan nila sebesar $75 \%$ dari total karamba. Berdasarkan hasil penelitian yang dilakukan di Nagari Maninjau dan Bayua hampir seluruh pembudidaya tersebut membudidayakan ikan nila. Selanjutnya dilakukan analisis terhadap budidaya ikan nila. Benih ikan nila yang ditebar untuk masing-masing karamba atau petak ukuran $5 \mathrm{~m} \times 5 \mathrm{~m} \times 4 \mathrm{~m}$ sebesar 10.000 ekor dengan harga Rp 120 per ekor. Rata-rata jumlah pakan yang diberikan sebanyak 1.500 kg sampai ikan dapat dipanen. Harga pakan ikan sebesar Rp. 5.800 per kg. Jumlah pakan yang telah diberikan sampai ikan-ikan tersebut mengalami kematian diperkirakan sebanyak $75 \%$ dari seluruh total pakan. Pengelolaan atau pelaksanaan operasional budidaya sebanyak 16 petak karamba dibutuhkan 1 orang tenaga kerja. Upah tenaga kerja Rp 500.000 per orang per bulan. Upah tenaga kerja dalam pemeliharaan 3 bulan ikan sebesar Rp 93.750 per petak. Penerangan yang diperlukan adalah 
1 buah lampu 20 watt untuk menerangi 4 petak. Tagihan listrik untuk 1 buah lampu diperkirakan Rp. 20.000 per bulan. Tagihan listrik untuk menerangi 1 petak karamba selama 3 bulan adalah Rp 15.000. Total biaya operasional selama 3 bulan pemeliharaan adalah $\mathrm{Rp} 7.833 .750$ per petak.

Biaya tetap terdiri dari biaya penyusutan investasi yang terdiri dari karamba, bambu, perahu dan rumah pakan.Biaya untuk pembuatan karamba yang terdiri dari jaring, kayu, tali, benang serta upah pembuatan sebesar Rp 4.820.000. Umur teknis karamba ini diperkirakan selama 5 tahun. Biaya penyusutan karamba selama 3 bulan adalah Rp 60.250 per petak. Bambu diperlukan sebagai pelampung karamba untuk karamba tradisional yang belum menggunakan drum. Sebagian besar karamba yang terdapat di Nagari Maninjau dan Nagari Bayua menggunakan bambu sebagai pelampung. Bambu yang diperlukan sebanyak 18 batang untuk 1 unit karamba jaring apung yang terdiri dari 4 karamba ukuran $5 \mathrm{~m} \times 5$ $\mathrm{m} \times 4 \mathrm{~m}$. Umur teknis bambu diperkirakan selama 1 tahun. Biaya penyusutan bambu selama 3 bulan adalah Rp 39.400 per petak. Perahu diperlukan pembudidaya sebagai sarana transportasi untuk mengangkut orang, mengangkut pakan dan mengangkut ikan hasil panen. Setiap keluarga yang memiliki karamba memiliki 1 buah perahu. Harga perahu kayu adalah Rp 1.000.000 dengan umur teknis selama 3 tahun. Biaya penyusutan perahu selama 3 bulan adalah Rp 10.400 per petak. Rumah pakan berfungsi untuk menyimpan pakan. rata-rata biaya yang diperlukan untuk membangun rumah pakan adalah $\mathrm{Rp} 2.000 .000$ dengan umur teknis selama 7 tahun. Biaya penyusutan rumah pakan selama 3 bulan adalah Rp 8.950 per petak. Total biaya tetap untuk budidaya selama 3 bulan pemeliharaan adalah Rp 119.000. Total biaya pemeliharaan selama 3 bulan untuk ikan nila adalah Rp 7.952.750 per petak. Dengan mengasumsikan $80 \%$ dari karamba yang terdapat di Nagari Maninjau dan Bayua yaitu 1.390, maka total kerugian yang dialami oleh pembudidaya di kedua nagari tersebut adalah 11,05 milyar. Rincian biaya operasional dan biaya tetap disajikan pada Tabel 1.

Tabel 1. Biaya Operasional dan Biaya Tetap Budidaya Ikan Sistem KJA Selama 3 Bulan Pemeliharaan di Danau Maninjau Sumatera Barat, 2010.

Table 1. Operating and Fixed Costs of Fish Farming Cages for 3 Months System Maintenance at Lake Maninjau West Sumatra, 2010.

1. Biaya operasional/ Operational cost

$\begin{array}{ll}\text { - } & \text { Bibit/ Seed } \\ \text { - } & \text { Pakan/ Feed } \\ \text { - } & \text { Upah tenaga kerja/ Wages of labour } \\ \text { - } & \text { Listrik/ Electricity } \\ \text { - } \quad \text { Total biaya operasional/ Total of operating costs }\end{array}$

2. Biaya tetap/ Fixed cost

- Penyusutan karamba/ Depreciation of cages

- Penyusutan bambu/ Depreciation of bamboo

- Penyusutan perahu/ Depreciation of boat

- Penyusutan rumah pakan/ Depreciation of home feed

- Total biaya tetap/ Total of fixed cost

3. Total Biaya/ Total cost
$1,200,000$

$6,525,000$

93,750

15,000

$7,833,750$

60,250

39,400

10,400

8,950

119,000

$7,952,750$

Sumber : Data Primer (April 2010).

Source : Primary Data (April, 2010). 


\section{KEUNTUNGAN PEMBUDIDAYA YANG HILANG}

Potensi keuntungan pembudidaya yang hilang adalah besarnya keuntungan yang tidak jadi diterima oleh pembudidaya karena adanya kejadian kematian ikan secara masal. Nilai ini diperoleh dari besarnya keuntungan usaha per karamba dikalikan dengan jumlah karamba yang ikan-ikannya mengalami kematian secara masal. Keuntungan usaha diperoleh dari total penerimaan dikurangi dengan total biaya. Total penerimaan diperoleh dari ratarata jumlah panen ikan nila per karamba dikalikan dengan harga ikan nila per kg di lokasi pembudidaya. Berdasarkan hasil penelitian, dengan menggunakan benih sebanyak 10.000 ekor dan pakan sebanyak $1.500 \mathrm{~kg}$ selama periode produksi, maka diperoleh ikan nila ukuran konsumsi sebanyak $1.050 \mathrm{~kg}$. Rata-rata harga ikan nila pada saat dilakukan penelitian adalah $\mathrm{Rp} 12.000$ per kg. Total penerimaan pembudidaya selama 1 periode produksi atau 1 musim tanam adalah $\mathrm{Rp}$ 12.600.000.
Total biaya diperoleh dari penjumlahan biaya operasional dan biaya tetap dengan waktu pemeliharaan selama 4 bulan. Biaya operasional terdiri dari biaya untuk pembelian benih, pakan, upah tenaga kerja dan pembayaran tagihan listrik. Rincian besarnya masing-masing biaya sama dengan penjelasan sebelumnya, tetapi waktu untuk satu periode produksi adalah 4 bulan. Total biaya operasional adalah Rp 10.045.000 per petak per periode produksi. Biaya tetap terdiri dari biaya untuk penyusutan investasi. Total biaya tetap adalah Rp 158.600 per petak per periode produksi. Total biaya per periode produksi adalah Rp 10.203.600. Keuntungan usaha setiap periode produksi adalah Rp 2.396.400 per petak. Potensi keuntungan pembudidaya yang hilang diperoleh dari besarnya keuntungan usaha masing-masing karamba dikalikan dengan total jumlah karamba. Potensi keuntungan pembudidaya yang hilang adalah $\mathrm{Rp} 2,62$ milyar. Total penerimaan, total biaya dan keuntungan usaha disajikan pada Tabel 2.

Tabel 2. Total Penerimaan, Total Biaya dan Keuntungan Usaha Budidaya Ikan Sistem KJA di Danau Maninjau, Sumatera Barat, 2010.

Table 2. Total Revenue, Total Cost and Profit of Fish Farming Systems in the Lake Maninjau KJA, West Sumatra, 2010.

\begin{tabular}{lr}
\hline \multicolumn{1}{c}{ Jenis Biaya/ Types of Costs } & Nilai (Rupiah)/ Value (IDR) \\
\hline 1. Jumlah produksi (Kg)/ Total production (Kgs) & 1,050 \\
2. Harga (Rp/Kg)/ Price (IDR/Kgs) & 12,000 \\
3. Total penerimaan/ Total revenue & $12,600,000$ \\
- Bibit/ Seed & $1,200,000$ \\
- Pakan/ Feed & $8,700,000$ \\
- Upah tenaga kerja/ Wages of labour & 125,000 \\
- Listrik/ Electricity & 20,000 \\
4. Total biaya operasional/ Total of operational cost & $10,045,000$ \\
- Penyusutan karamba/ Depreciation of cages & 80,300 \\
- Penyusutan bambu/ Depreciation of bamboo & 52,500 \\
- Penyusutan perahu/ Depreciation of boat & 13,900 \\
- Penyusutan rumah pakan/ Depreciation of home feed & 11,900 \\
5. Total biaya tetap/ Total Fixed Cost & 158,600 \\
6. Total biaya/ Total cost & $10,203,600$ \\
7. Keuntungan/ Profit & $2,396,400$ \\
\hline
\end{tabular}

Sumber : Data Primer (April 2010).

Source : Primary Data (April, 2010). 


\section{KEUNTUNGAN PEDAGANG YANG HILANG}

Potensi keuntungan pedagang pakan yang hilang diketahui dari besarnya keuntungan yang tidak diterima oleh pedagang pakan karena sebagian besar ikan yang dibudidayakan di Nagari Maninjau dan Nagari Bayua mengalami kematian. Dengan adanya kejadian kematian ikan secara masal maka permintaan terhadap pakan menjadi berkurang. Ikan-ikan yang mengalami kematian diperkirakan berumur lebih dari 2 bulan, dengan kata lain, ikan yang berumur kurang dari 2 bulan masih bertahan hidup. Oleh karena itu, jumlah pakan yang telah dikonsumsi oleh ikan-ikan yang mati tersebut diperkirakan $75 \%$ dari total jumlah pakan untuk satu periode produksi. Jumlah pakan yang tidak terpakai untuk periode produksi tersebut adalah $25 \%$ dari total jumlah pakan. Total pakan yang tidak terpakai adalah $25 \%$ dari $1.500 \mathrm{~kg}$ yaitu $375 \mathrm{~kg}$ atau 7,5 sak. Pakan ikan yang tidak terpakai di kedua nagari tersebut adalah 410 ton atau 8.200 sak.

Pedagang pakan ikan memperoleh keuntungan Rp 50 hingga Rp 100 per kg pakan. Berdasarkan hasil penelitian rata-rata keuntungan pedagang pakan adalah Rp 70 per $\mathrm{kg}$. Total potensi keuntungan pedagang pakan yang hilang adalah Rp 28,73 juta. Jumlah pedagang pakan ikan diketahui sebanyak 15 orang. Jika penjualan pakan tersebar secara merata kepada seluruh pedagang pakan, maka potensi keuntungan yang hilang dari masingmasing pedagang adalah Rp.1.915.000.-

Kematian ikan secara masal juga berdampak kepada pedagang ikan selain pembudidaya dan pedagang pakan ikan. Hilangnya potensi keuntungan para pedagang ikan disebabkan karena ikan-ikan tersebut tidak jadi dijual, sehingga pedagang tidak memperoleh keuntungan. Berdasarkan hasil penelitian diperoleh, total jumlah ikan yang mengalami kematian adalah 1.149 ton. Hal ini sejalan dengan berita yang telah dipublikasikan sebelumnya yang mengatakan bahwa total kematian ikan di Danau Maninjau pada awal tahun 2010 adalah 1.150 ton. Dengan asumsi pedagang ikan memperoleh keuntungan $\mathrm{Rp}$ 200 per kg ikan yang dijual, maka keuntungan yang hilang adalah Rp 229,80 juta.

Kematian ikan budidaya sistem KJA di Danau Maninjau tidak hanya berdampak kepada pembudidaya, melainkan juga berdampak kepada seluruh aktivitas yang terkait dengan usaha tersebut. Dalam penelitian ini difokuskan hanya dampak terhadap pembudidaya, pedagang pakan ikan dan pedagang ikan. Dampak yang dikaji adalah potensi keuntungan yang hilang dari masing-masing pelaku usaha tersebut. Total kerugian yang dialami oleh masyarakat secara ekonomi akibat kejadian kematian ikan pada periode 23 Februari - 13 Maret 2010 adalah Rp 13,93 milyar.

\section{DAMPAK SOSIAL KEMATIAN IKAN SECARA MASAL}

Kejadian kematian ikan secara masal tidak hanya berdampak secara ekonomi tetapi juga menyebabkan dampak sosial kepada masyarakat. Dampak sosial ditinjau dari hilangnya sumber matapencaharian sejumlah tenaga kerja, adanya peningkatan hutang untuk melanjutkan usaha dan terjadinya penurunan kualitas konsumsi masyarakat yang terkena dampak secara langsung.

Tenaga kerja yang terkait langsung dengan usaha budidaya sistem KJA antara lain: tenaga kerja pemberi pakan, tenaga kerja untuk pelaksana panen dan sopir yang menghantarkan ikan dari lokasi budidaya di Danau Maninjau ke pasar-pasar tujuan perdagangan ikan. Tenaga kerja pemberi pakan adalah tenaga kerja yang dibayar dengan tugas utamanya memberikan pakan kepada ikan-ikan di dalam karamba. Setiap satu orang tenaga kerja dapat ditugaskan untuk memberi pakan sebanyak 16 petak karamba. Tenaga kerja ini biasanya digaji sebesar Rp 500.000 per bulan. Pada saat kejadian kematian ikan, tenaga kerja ini diminta untuk membantu menyelamatkan ikan yang masih dapat diselamatkan dan juga diminta untuk membantu membersihkan karamba dari sejumlah ikan-ikan yang mati. Bagi pembudidaya yang memiliki modal cukup besar, maka tenaga kerja ini akan diberikan tambahan insentif atas kegiatan yang telah dilakukannya. 
Tenaga kerja yang merasakan dampak yang cukup signifikan karena adanya kematian ikan secara masal ini adalah tenaga kerja pelaksana panen. Tenaga kerja pelaksana panen ini biasanya bekerja secara berkelompok dan bekerjasama dengan pedagang ikan. Sistem pembelian ikan yang dilakukan oleh pedagang ikan adalah membeli ikan yang masih terdapat di dalam karamba. Seluruh upah untuk pemanenan di tanggung oleh pembeli. Aktivitas pemanenan dimulai dari pengisian air bersih kedalam kantong plastik di tempat pengisian air bersih. Setelah itu, kantongkantong yang telah berisi air bersih dibawa ke lokasi pemanenan. Sebagian tenaga kerja bertugas untuk menangkap ikan, melakukan penimbangan, mengangkut ikan dari perairan ke daratan, pemindahan ikan kedalam kantong yang telah berisi air bersih dan pengisian oksigen untuk selanjutnya di ikat dan dimuat ke moda transportasi.

Banyaknya tenaga kerja untuk melakukan seluruh aktivitas panen ini berkisar 10-12 orang. Upah yang diberikan oleh pedagang setiap melakukan panen adalah Rp 500.000 per petak dengan jumlah panen 1.000 - $1.500 \mathrm{~kg}$. Total potensi upah tenaga kerja yang hilang karena 1.094 karamba tidak dapat di panen adalah Rp 547,5 juta. Diketahui jumlah tenaga kerja untuk panen yang terdapat di Nagari Maninjau dan Nagari Bayua adalah 300 orang. Masingmasing tenaga kerja mengalami kehilangan upah sebesar Rp 1.823.000 atau setara dengan 36 petak karamba yang tidak jadi di panen.

Air yang digunakan untuk mengangkut ikan adalah air yang bersumber dari mata air yang terdapat di nagari. Banyaknya jumlah oksigen untuk masing-masing kantong tergantung dari tujuan pemasaran ikan tersebut. Semakin jauh tujuan pemasaran, maka jumlah oksigen yang diberikan semakin banyak. Setiap kantong berisikan sekitar 7 kg ikan nila. Moda transportasi yang umum digunakan untuk tujuan pemasaran yang lebih jauh adalah truk dengan 6 roda. Muatan truk tersebut berkisar antara $1.200 \mathrm{~kg}-1.800$ kg. Kemudian, untuk tujuan pemasaran yang lebih dekat seperti Kota Padang, Bukit Tinggi, Payakumbuh, Solok dan Lubuk Basung menggunakan mobil pick up dengan muatan maksimum $800 \mathrm{~kg}$.

Tenaga kerja lainnya yang merasakan dampak kematian masal ikan ini adalah supir yang menghantarkan ikan hasil produksi ke pasar. Rata-rata muatan truk dalam mengantar barang ke pasar adalah $1.400 \mathrm{~kg}$. Dengan jumlah kematian ikan 1.150 ton, maka terdapat 821 trip truk yang tidak terlaksana. Supir truk ini terdiri dari 1 sampai 2 orang, sesuai dengan jarak angkut. Pasar yang jauh seperti Medan, Jambi dan Pekanbaru menggunakan 2 orang supir. Hal ini dilakukan supaya ikan dapat sampai di pasar lebih cepat. Supir akan berusaha supaya dapat lebih cepat sampai di pasar, karena dengan waktu yang lebih lama akan menyebabkan kematian ikan yang lebih banyak. Ikan dalam kondisi hidup dihargai lebih mahal dibandingkan ikan yang sudah mati. Rata-rata upah supir untuk mengangkut ikan-ikan dapat sampai ke pasar adalah Rp 250.000 per trip. Total upah yang tidak diterima oleh para supir karena adanya kematian ikan secara masal adalah Rp 205 juta.

Dampak lain yang ditanggung oleh masyarakat atau pembudidaya akibat adanya kematian ikan secara masal adalah meningkatnya jumlah hutang. Pembudidaya yang hanya memiliki modal secukupnya untuk menjalankan usaha budidaya ikan akan mencari sumber modal baru setelah semua ikan yang dimilikinya mengalami kematian secara masal. Hutang diperlukan untuk dapat terus melanjutkan usaha dibidang budidaya, tanpa adanya bantuan atau tambahan modal, maka pembudidaya akan berhenti dan tidak akan melanjutkan usahanya kembali. Bantuan modal ini diperoleh dari pengusaha atau perseorangan yang memiliki modal lebih banyak. Bantuan modal yang diberikan berupa bantuan untuk pembelian benih dan pakan. Pembudidaya dapat membuat perjanjian dengan pelaku pembenihan yang menyediakan benih dan juga pedagang ikan untuk mendapatkan pakan. Perjanjian yang dilakukan terhadap penyedia benih adalah benih akan dibayar setelah nanti ikan hasil budidaya di panen. Begitu juga perjanjian yang dilakukan dengan pedagang pakan. Pakan akan dibayar setelah ikan-ikan 
hasil budidaya dijual. Penyedia pakan untuk pembudidaya di Danau Maninjau dikuasai oleh satu orang pengusaha yang merupakan putra daerah Danau Maninjau. Pangsa pasar untuk pakan ikan yang dikuasai oleh pengusaha ini lebih kurang 30\% dari total kebutuhan pakan di Danau Maninjau.

Jumlah pembudidaya di Nagari Maninjau dan Nagari Bayua yang harus melakukan peminjaman untuk melanjutkan usahanya diperkirakan 30\% dari seluruh kepala keluarga pembudidaya. Total jumlah pembudidaya untuk kedua nagari tersebut adalah 334 kepala keluarga. Kebutuhan masing-masing kepala keluarga untuk melanjutkan usaha sampai pada kondisi optimal adalah Rp 40 juta. Total kebutuhan modal bagi pembudidaya untuk dapat bangkit dan melanjutkan usahanya seperti sebelum terjadi kematian ikan secara masal adalah Rp 4 milyar.

\section{ANTISIPASI SOLUSI DAN KEBIJAKAN PENANGANAN}

Dampak ekonomi kematian massal ikan budidaya yang terjadi pada 2 nagari di Danau Maninjau pada periode pada periode 23 Februari - 13 Maret 2010 adalah Rp 13,93 milyar. Kerugian tersebut terdiri atas dampak kerugian ekonomi kematian ikan, potensi keuntungan yang hilang bagi pembudidaya ikan, pedagang pakan ikan dan pedagang ikan. Dengan kata lain, dampak kerugian ekonomi tersebut merupakan potensi pendapatan yang hilang bagi pembudidaya, pedagang pakan ikan dan pedagang ikan. Dengan asumsi $80 \%$ dari karamba yang terdapat di Nagari Maninjau dan Bayua yaitu 1.390, maka total kerugian yang dialami oleh pembudidaya di kedua nagari tersebut adalah Rp.11,05 milyar. Potensi keuntungan pembudidaya yang hilang adalah besarnya keuntungan yang tidak jadi diterima oleh pembudidaya karena adanya kejadian kematian ikan secara masal, yang mencapai nilai Rp.2,62 milyar. Di lain pihak, potensi keuntungan pedagang pakan yang hilang dengan adanya kejadian kematian ikan secara masal mencapai nilai Rp.28,73 juta.
Dan kemudian, dengan dasar penelitian yang diperoleh, total jumlah ikan yang mengalami kematian adalah 1.149 ton, maka keuntungan yang hilang adalah Rp 229,80 juta.

Di lain pihak, dampak sosial yang diperhitungkan secara ekonomi yang diketahui antara lain berasal dari hilangnya sumber matapencaharian sejumlah tenaga kerja, adanya peningkatan hutang untuk melanjutkan usaha dan terjadinya penurunan kualitas konsumsi masyarakat yang terkena dampak secara langsung. Tenaga kerja yang terkait langsung dengan usaha budidaya sistem KJA antara lain: tenaga kerja pemberi pakan, tenaga kerja untuk pelaksana panen dan sopir yang menghantarkan ikan dari lokasi budidaya di Danau Maninjau ke pasar-pasar tujuan perdagangan ikan. Adapun total potensi upah tenaga kerja yang hilang karena 1.094 karamba tidak dapat di panen adalah Rp 547,5 juta. Kemudian, total upah yang tidak diterima oleh para supir karena adanya kematian ikan secara masal adalah Rp 205 juta. Dan, total kebutuhan modal bagi pembudidaya untuk dapat bangkit dan melanjutkan usahanya seperti sebelum terjadi kematian ikan secara masal adalah Rp 4 milyar.

Dengan adanya kematian masal ikan yang saat ini sudah berulang-ulang, terlihat bahwa belum ada suatu tindakan yang secara nyata dapat memberikan dampak positif jangka panjang dalam menanggulangi akar permasalahan yang terjadi di perairan Danau Maninjau ini. Akar permasalahan yang mengakibatkan terjadinya kematian ikan ini ternyata ada pengaruh faktor alami yang tidak dapat dikendalikan, yaitu kedatangan angin kencang yang dapat mengaduk perairan yang datangnya tidak dapat diprediksi secara tepat kapan waktunya. Namun demikian, dari beberapa tahun kejadian kematian ikan dapat diduga bahwa periode kedatangan angin kencang yang berpengaruh kepada perairan Danau Maninjau terjadi antara periode JanuariMaret atau Oktober-Desember. Oleh karena itu dengan dasar dua periode tersebut, maka periode tanam ikan pada budidaya ikan system keramba jarring apung harus dilakukan pada periode April hingga September. 
Alternatif penanggulangan yang secara bio-ekologis dapat mengurangi beban sumber pencemaran adalah dengan cara mengurangi kemungkinan jumlah sisa pakan yang terbuang ke dalam perairan Danau Maninjau. Dalam hal ini ada dua cara, yang pertama melalui penerapan system budidaya ikan yang menerapkan system KJA Ganda. Sistem KJA Ganda ini memiliki kelebihan dibandingkan dengan sistem keramba satu lapis dalam hal pakan yang dimanfaatkan ikan yang dipelihara pada keramba yang dibawah tidak perlu diberi pakan. Diharapkan ikan ini memanfaatkan pakan sisa dari pakan yang diberikan pada keramba diatasnya. Umumnya keramba bawah diisi dengan jenis ikan pemakan segala (omnivore), sedangkan ikan pada keramba diatasnya dapat dipelihara ikan mas atau ikan patin. Cara yang kedua adalah dengan pembatasan ketat terhadap jumlah KJA yang diperbolehkan untuk dioperasikan pada seluruh wilayah perairan Danau Maninjau berdasarkan daya dukung lingkungan perairan tersebut.

Terkait dengan jumlah KJA yang dapat ditampung di perairan Danau Maninjau, LIPI (2009) telah menentukan sejak awal (tahun 2002) bahwa jumlah KJA maksimum yang dapat didukung oleh lingkungan perairan danau tersebut adalah 1.500 unit. Oleh karena itu, harus dilakukan pengurangan jumlah KJA yang saat ini telah mencapai 15.050 unit menjadi hanya 1.500 unit saja. Penerapan cara kedua ini, memerlukan sistem pengawasan dan pemantauan terhadap KJA yang beroperasi di perairan Danau Maninjau, yang perlu pula didukung sarana dan prasarananya, sumberdaya manusia pengawas yang handal serta penegakan aturan yang konsisten.

Dua alternatif cara yang dikemukakan diatas merupakan cara yang harus ditempuh jika aktivitas budidaya ikan sistem KJA tetap ingin dilanjutkan di perairan Danau Maninjau ini. Tanpa pembatasan jumlah KJA dan penerapan sistem KJA Ganda, maka kejadian kematian ikan secara masal akan semakin sering terjadi dan berulang dalam waktu yang semakin singkat. Namun demikian, kedua cara tersebut akan lebih baik jika dilakukan pula secara bersamaan proses pengaliran arus yang dilakukan melalui saluran utamanya yang alami, disamping saluran "intake" yang diatur terkait dengan pembangkit tenaga listrik (PLTA).

Beberapa langkah penanggulangan yang merupakan solusi terhadap permasalahan yang dihadapi serta sekaligus berkaitan dengan kegiatan pengelolaan danau secara keseluruhan, maka implikasi opsi kebijakan yang dapat dilaksanakan antara lain adalah;

1) Melakukan penghentian sementara kegiatan budidaya hingga kondisi cuaca membaik dan tingkat pencemaran sudah mulai normal, lalu melaksanakan pembersihan bangkai ikan mati sesegera mungkin. Dalam hal ini masyarakat harus pula diarahkan untuk melaksanakan penangkapan ikan, atau mencari alternatif penghasilan lainnya, diluar perikanan.Terkait dengan kegiatan ini, dinas setempat (kerjasama dengan DJPB) telah merencanakan perlu pengadaan sarana transportasi air (pompong) untuk KJA sebanyak 50 unit dengan dana Rp.420.000.000.- yang tersebar di wilayah sekeliling danau. Hal ini, juga didukung dengan pembangunan Darmaga Tambat Labuh Panen Ikan KJA sebanyak 5 unit dengantotal dana sebesar Rp.800.000.000.serta Depo Bongkar Muat Ikan KJA sebanyak 10 paket yang memerlukan dana sebesar Rp.360.000.000.-

2) Penyedotan dan/atau pengerukan limbah aktivitas budidaya ikan dari dasar perairan. Limbah tersebut dapat dimanfaatkan sebagai pupuk penyubur tanaman. Dalam hal ini, dapat pula dilakukan melalui upaya pengurangan laju jumlah polutan secara organik melalui budidaya kerang atau jenis biota lain yang dapat mengkonsumsi atau mengurai limbah budidaya sehingga tidak menjadi racun. Disamping itu, juga dapat dibarengi dengan upaya mengurangi limbah aktivitas budidaya ikan dengan cara memberikan penyuluhan kepada masyarakat pembudidaya terkait dengan Cara Budidaya Ikan yang Baik (CBIB) yang dapat pula ditambah dengan penerapan sistem budidaya menggunakan cara KJA 
Ganda. Dalam hal ini, telah direncanakan oleh Dinas Kelautan dan Perikanan Kabupaten Agam pada tahun 2011 adanya kegiatan kerjasama antara Direktorat Jenderal Perikanan Budidaya (DJPB) Kementerian Kelautan dan Perikanan, yaitu berupa 8 petak Dempond KJA Ramah Lingkungan (Mas dan Nila) serta 4 petak Dempond KJA Ikan Patin dengan dana sebesar Rp.275.000.000.-

3) Pengaturan kembali jumlah dan tata letak KJA dengan memperhatikan daya dukung lingkungan sesuai hasil riset dan penetapannya melalui Perda Kabupaten setempat. Hal ini sesuai dengan amanat Peraturan Bupati Kabupaten Agam No.22 Tahun 2009 Tentang Pengelolaan Danau Maninjau, yang memperlihatkan bahwa penetapan zonasi di perairan Danau Maninjauinibelumterlaksanasebagaimana mestinya.Bahkan dalam peraturan Bupati tersebut telah dinyatakan bahwa penempatan karamba harus berjarak $50 \mathrm{~m}$ dari pinggir danau (untuk kawasan Barat di Nagari Tanjung Sani dan Batu Nanggai) dan 100 m untuk kawasan timur (Nagari Koto Malintang, Koto Gadang, Koto Kaciak, Duo Koto, Bayua, Maninjau, dan Sungai Batang). Kemudian, untuk jumlah KJA maksimum telah juga ditetapkan dalam peraturan Bupati ini, yaitu sebanyak 1.500 unit dengan jarak minimal $10 \mathrm{~m}$ antar unit KJA. Perlu pula dipikirkan bagaimana peran adat atau kelembagaan adat terkait dengan penegakan aturan di sekeliling danau ini kaitannya dengan pengelolaan sumberdaya perikanan di Danau Maninjau secara keseluruhan.

4) Solusi untuk melanjutkan usaha bagi pembudidaya yang hanya memiliki modal secukupnya dan mengalami kematian ikan, maka diperlukan modal biaya operasional yang baru. Agar mereka tidak terjerat hutang kepada pemilik modal dan atau hanya bekerja sebagai buruh, maka penyediaan pinjaman berbunga rendah sangat diperlukan. Keperluan biaya operasional yang diperlukan per kepala keluarga sekitar Rp.40 juta. Sementara jumlah mereka yang memerlukan sekitar $30 \%$ dari jumlah kepala keluarga di 2 nagari tersebut (sekitar $100 \mathrm{KK}$ ), sehingga diperlukan dana untuk mereka sekitar Rp.4 milyar, agar pembudidaya ikan akan melanjutkan usahanya kembali. Hal ini kiranya perlu dipertimbangkan penyaluran Skim Kredit tertentu baik berupa dana yang berasal dari PNPM Mandiri KP ataupun Kredit Usaha Rakyat (KUR).

5) Pembangunan sistem pemantauan yang difungsikan sebagai sistem peringatan dini terhadap datangnya fenomena alam. Hal ini dapat dikaitkan dengan pengaturan waktu tanam yang telah dikemukakan diatas dan dibarengi pula dengan penebaran benih ikan unggul, dan sesuai dengan kondisi perairan danau atau jenis ikan yang dapat bertahan hidup pada kondisi oksigen rendah (misalnya patin). Dalam hal ini, untuk menjamin ketahanan benih ikan terhadap penyakit, maka diperlukan adanya Laboratorium Kesehatan Ikan dan Lingkungan. Dalam hal ini, ada rencana dari Dinas Kelautan dan Perikanan Kabupaten Agam (kerjasama dengan DJPB) untuk membangun 1 paket Pembangunan / Pengadaan Sarana dan Prasarana Laboratorium Kesehatan Ikan dan Lingkungan dengan dana sebesar Rp.1,7 milyar.Dalam hal ini, termasuk pula rencana pembangunan 4 paket Pos Pengawasan dan Pengendalian Distribusi dan Kesehatan Ikan sebesar Rp.40.000.000.- yang diharapkan dapat berfungsi sebagai sarana pemantauan kualitas ikan, terutama benih ikan yang akan dipergunakan untuk kegiatan budidaya.

\section{PENUTUP}

Dampak ekonomi kematian massal ikan budidaya yang terjadi pada 2 nagari di Danau Maninjau pada periode pada periode 23 Februari - 13 Maret 2010 adalah Rp 13,93 milyar. Kerugian tersebut terdiri atas dampak kerugian ekonomi kematian ikan, potensi keuntungan yang hilang bagi pembudidaya 
ikan, pedagang pakan ikan dan pedagang ikan. Dampak sosial yang diperhitungkan secara ekonomi yang diketahui berasal dari hilangnya sumber matapencaharian sejumlah tenaga kerja, adanya peningkatan hutang untuk melanjutkan usaha dan terjadinya penurunan kualitas konsumsi masyarakat yang terkena dampak secara langsung. Tenaga kerja yang terkait langsung dengan usaha budidaya sistem KJA yaitu: tenaga kerja pemberi pakan, tenaga kerja untuk pelaksana panen dan sopir yang menghantarkan ikan dari lokasi budidaya di Danau Maninjau ke pasar-pasar tujuan perdagangan ikan.

Alternatif penanggulangan yang secara bio-ekologis dapat mengurangi beban sumber pencemaran adalah dengan cara mengurangi kemungkinan jumlah sisa pakan yang terbuang ke dalam perairan Danau Maninjau. Dalam hal ini ada dua cara, yang pertama melalui penerapan system budidaya ikan yang menerapkan system KJA Ganda. Sistem KJA Ganda ini memiliki kelebihan dibandingkan dengan sistem keramba satu lapis dalam hal pakan yang dimanfaatkan ikan yang dipelihara pada keramba yang dibawah tidak perlu diberi pakan. Diharapkan ikan ini memanfaatkan pakan sisa dari pakan yang diberikan pada keramba diatasnya. Umumnya keramba bawah diisi dengan jenis ikan pemakan segala (omnivore), sedangkan ikan pada keramba diatasnya dapat dipelihara ikan mas atau ikan patin. Cara yang kedua adalah dengan pembatasan ketat terhadap jumlah KJA yang diperbolehkan untuk dioperasikan pada seluruh wilayah perairan Danau Maninjau berdasarkan daya dukung lingkungan perairan tersebut.

Beberapa langkah penanggulangan yang merupakan solusi terhadap permasalahan yang dihadapi serta sekaligus berkaitan dengan kegiatan pengelolaan danau secara keseluruhan, maka implikasi opsi kebijakan yang dapat dilaksanakan antara lain adalah; (a) melakukan penghentian sementara kegiatan budidaya hingga kondisi cuaca membaik dan tingkat pencemaran sudah mulai normal, lalu melaksanakan pembersihan bangkai ikan mati sesegera mungkin; (b) penyedotan dan/atau pengerukan limbah aktivitas budidaya ikan dari dasar perairan. Limbah tersebut dapat dimanfaatkan sebagai pupuk penyubur tanaman; (c) pengaturan kembali jumlah dan tata letak KJA dengan memperhatikan daya dukung lingkungan sesuai hasil riset dan penetapannya melalui Perda Kabupaten setempat. Hal ini sesuai dengan amanat Peraturan Bupati Kabupaten Agam No.22 Tahun 2009 Tentang Pengelolaan Danau Maninjau, yang memperlihatkan bahwa penetapan zonasi di perairan Danau Maninjau ini belum terlaksana sebagaimana mestinya; (d) perlu pula dipikirkan bagaimana peran adat atau kelembagaan adat terkait dengan penegakan aturan di sekeliling danau ini kaitannya dengan pengelolaan sumberdaya perikanan di Danau Maninjau secara keseluruhan; (e) solusi untuk melanjutkan usaha bagi pembudidaya yang hanya memiliki modal secukupnya dan mengalami kematian ikan, maka diperlukan modal biaya operasional yang baru. Keperluan biaya operasional yang diperlukan per kepala keluarga sekitar Rp.40 juta; (f) pembangunan sistem pemantauan yang difungsikan sebagai sistem peringatan dini terhadap datangnya fenomena alam.

\section{DAFTAR PUSTAKA}

Dunn, 2000. Dunn, W. N., 2000. Pengantar Analisis Kebijakan Publik. Edisi Kedua. Gadjah Mada University Press. Yogyakarta. 687 p.

Hare, W.L., J.P. Marlow, M.L. Rae., F. Gray., R. Humphries., and R. Ledgar., 1990, Ecologically Sustainable Development, A Submission ACF, Greenpeace, The Wilderness Society and WWF For Nature - Australia, Australian Conservation Foundation, Fitzroy, Australia.

Kartamihardja, E.S., 1995, Daya Dukung Perairan dan Pengembangan Budidaya Ikan Dalam Keramba Jaring Apung yang Ramah Lingkungan, Prosiding Expose Budidaya Ikan dalam KJA yang Ramah Lingkungan, hal. 13-22, Balai Penelitian Perikanan Air Tawar, Sukamandi, Jawa Barat. 
Krismono, 1996, Umbalan, Dampak dan Penanggulangannya, Warta Penelitian dan Pengembangan Pertanian, Vol.XVIII, No. 5, Badan Litbang Pertanian, Deptan.

Krismono dan A. Krismono, 1998, Mengapa Ikan Dalam Keramba Jaring Apung di Danau dan Danau Mati?, Warta Penelitian Perikanan Indonesia, hal. 12-16, Puslitbang Perikanan, Badan Litbang Pertanian, Deptan.

LIPI, 2009. Program Penyehatan Danau Maninjau dan Pemberdayaan Masyarakat di Sekitar Danau; Ringkasan Kegiatan LIPI di Danau Maninjau Tahun 2001-2009. Pusat Penelitian Limnologi, Lembaga IImu Pengetahuan Indonesia.

Nazir, M. 1988. Metode Penelitian. Ghalia Indonesia. Jakarta.
Sawyer, C. N., 1969, Basic concepts of

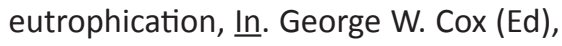
Reading in Conservation Ecology, pp.462472, Appleton-Century-Crofts, Meredith Corporation, New York.

Simatupang, P., 2003. Analisis Kebijakan: Konsep Dasar dan Prosedur Pelaksanaan. Analisis Kebijakan Pertanian. Pusat Penelitian dan Pengembangan Sosial Ekonomi Pertanian. Badan Penelitian dan Pengembangan Pertanian. Departemen Pertanian. I (1): 14-35.

Syandri, H. 2004. Penggunaan Ikan Nilem (Osteochilus hasellti CV) dan Ikan Tawes (Puntius javanicus CV) sebagai Agen Hayati Pembersih Perairan Danau Maninjau, Sumatera Barat. Jurnal Natur Indonesia 6 (2). hal 87-90. 